\title{
Hypocellular Tissue
}

National Cancer Institute

\section{Source}

National Cancer Institute. Hypocellular Tissue. NCI Thesaurus. Code C82997.

A morphologic finding indicating the presence of a small population of cells in a tissue sample. 